\title{
Renal Interactions of Renin-Angiotensin System, Nitric Oxide and Superoxide Anion: Implications in the Pathophysiology of Salt- Sensitivity and Hypertension
}

\author{
L. KOPKAN ${ }^{1,2}$, L. ČERVENKA ${ }^{1,2}$ \\ ${ }^{1}$ Center for Cardiovascular Research, ${ }^{2}$ Department of Experimental Medicine, Institute for Clinical \\ and Experimental Medicine, Prague, Czech Republic
}

Received August 17, 2009

Accepted October 30, 2009

\begin{abstract}
Summary
Renin-angiotensin system (RAS) plays a key role in the regulation of renal function, volume of extracellular fluid and blood pressure. The activation of RAS also induces oxidative stress, particularly superoxide anion $\left(\mathrm{O}_{2}^{-}\right)$formation. Although the involvement of $\mathrm{O}_{2}^{-}$production in the pathology of many diseases is known for long, recent studies also strongly suggest its physiological regulatory function of many organs including the kidney. However, a marked accumulation of $\mathrm{O}_{2}^{-}$in the kidney alters normal regulation of renal function and thus may contribute to the development of salt-sensitivity and hypertension. In the kidney, $\mathrm{O}_{2}^{-}$acts as vasoconstrictor and enhances tubular sodium reabsoption. Nitric oxide (NO), another important radical that exhibits opposite effects than $\mathrm{O}_{2}{ }^{-}$, is also involved in the regulation of kidney function. $\mathrm{O}_{2}^{-}$rapidly interacts with $\mathrm{NO}$ and thus, when $\mathrm{O}_{2}^{-}$production increases, it diminishes the bioavailability of NO leading to the impairment of organ function. As the activation of RAS, particularly the enhanced production of angiotensin $\mathrm{II}$, can induce both $\mathrm{O}_{2}^{-}$and $\mathrm{NO}$ generation, it has been suggested that physiological interactions of RAS, $\mathrm{NO}$ and $\mathrm{O}_{2}^{-}$provide a coordinated regulation of kidney function. The imbalance of these interactions is critically linked to the pathophysiology of salt-sensitivity and hypertension.
\end{abstract}

\section{Key words}

Renin-angiotensin system • Superoxide anion • Nitric oxide • Renal function • Salt-sensitivity • Hypertension

\section{Corresponding author}

L. Kopkan, Department of Experimental Medicine, Institute for Clinical and Experimental Medicine, Vídeňská 1958/9, 14000 Prague 4, Czech Republic. Fax: +4202 41721666. E-mail: likp@ikem.cz

\section{Introduction}

In recent years, the pathophysiological aspects of excessive salt intake as an important contributor to the high prevalence of cardiovascular diseases including hypertension have been investigated in many studies (Franco and Oparil 2006, Mancia et al. 2007). Responsible mechanisms have been examined in clinical as well as experimental research by evaluating the responses during manipulation of dietary sodium intake (Hall et al. 1980, Jackson and Navar 1986, Sagnella et al. 1989, Midgley et al. 1996, Poch et al. 2001). The blood pressure response to changes in salt intake displays an individual variability leading to salt resistance or salt sensitivity (Weinberger et al. 2001, Haddy 2006). A various salt intake induces changes in regulation of sodium and extracellular volume homeostasis particularly by the kidney (Guyton et al. 1972). The renal hemodynamic and tubular function maintaining physiological sodium and extracellular fluid volume are regulated by several systems such as renin-angiotensin system (RAS), system of nitric oxide (NO) and reactive oxygen species (ROS), primarily superoxide anion $\left(\mathrm{O}_{2}^{-}\right)$ (Romero and Reckelhoff 1999).

It is generally recognized that RAS plays an important role in the regulation of blood pressure and renal function (Hall et al. 1980, Jackson and Navar 1986, Poch et al. 2001). In the kidney, the key role of RAS in the regulation of sodium and extracellular fluid homeostasis has been studied extensively and an inverse relationship between salt intake and RAS activity at 
physiological state is now well established (Barri and Wilcox 1998, Husková et al. 2006). The relationship between fluid volume, sodium and endogenous RAS activity is critical for maintenance of normal blood pressure level. An enhanced activity of RAS can alter this relationship leading to the development of hypertension (Navar 2004, Kopkan et al. 2005, Husková et al. 2006). Angiotensin II (ANG II), as a major vasoactive agent, is responsible for physiological as well as pathophysiological effects of RAS (Navar 2004). Moreover, ANG II is a known stimulus for the formation of $\mathrm{O}_{2}^{-}$via activation of $\mathrm{NAD}(\mathrm{P}) \mathrm{H}$ oxidase (Nox) enzyme (Rajagopalan et al. 1996, Romero and Reckelhoff 1999). Three different Nox isoforms have been isolated in the kidney: Nox1, gp91 $1^{\text {phox }}$ called also as Nox 2 and Nox4; however, Nox4 seems to be most abundant (Gill and Wilcox 2006). Nox enzymes are expressed along the renal vessels and nephrons and Nox activity is upregulated not only by ANG II but also by high salt intake (Hannken et al. 1998, Kitiyakara et al. 2003). Although $\mathrm{O}_{2}^{-}$is produced by many other oxidizing enzymes and mitochondria, their induction by ANG II or high salt is not clearly defined. Furthermore, prolonged effects of both ANG II and high salt diet can reduce the expression of defense system against $\mathrm{O}_{2}^{-}$such as superoxide dismutase (Chabrashvili et al. 2003, Kitiyakara et al. 2003, Welch et al. 2005). Thus increased production of ROS and their reduced degradation can lead to the oxidative stress with wide physiological and pathophysiological consequences. In the kidney, it has been clearly shown that increased $\mathrm{O}_{2}^{-}$activity induces vasoconstriction and enhances tubular sodium reabsoptive function (Majid and Nishiyama 2002, Makino et al. 2002). These direct renal effects may be significantly involved in the pathophysiology of saltsensitive hypertension.

Another system that plays an important role in the regulation of blood pressure and renal function is a group of enzymes producing NO (called NO synthases; NOS). There are three isoforms of NOS (neuronal, nNOS; inducible, iNOS and endothelial, eNOS). Although the kidney contains all three isoforms, they are expressed along the blood vessels and nephron segments differently (Bachmann et al. 1995, Wu et al. 1999, Tojo et al. 2000, Herrera et al. 2006). NO is a very short-lived active free radical that exerts a wide range of physiological action (Romero and Reckelhoff 1999, Wink et al. 2001, Wilcox 2005). NO is characterized as a major vasodilator agent regulating basal vascular tone and it also inhibits renal tubular transport of sodium and thus plays an important role in overall excretory function of the kidney (Majid and Navar 2001, Wilcox 2005). Interestingly, eNOS that is considered to be the main source of NO production can be also induced by ANG II (Chin et al. 1999, Moreno et al. 2002). On the other hand, an excessive salt intake may also activate iNOS and nNOS in the kidney (Mattson and Higgins 1996, Tan et al. 2000, Schneider et al. 2008). Thus NO provides a protective role against several factors such as salt loading, oxidation or vasoconstrictors in the control of renal function (Zou et al. 1998, Chin et al. 1998, Lopez et al. 2003, Kopkan and Majid 2005, Červenka et al. 2008). The functional NO system is required for the maintenance of sodium and extracellular fluid homeostasis and any alterations in NO production lead to the impairment of organ function including the kidney.

Thus, in this minireview, we would like to focus on the current understanding of the involvement of renal interactions between RAS, $\mathrm{NO}$ and $\mathrm{O}_{2}^{-}$in the coordinated regulation of kidney function. As a central role of the kidney in the sodium and extracellular fluid homeostasis and thus long-term blood pressure regulation is still supported by current evidence, a further aim of our minireview is to consider the consequences of imbalance in these interactions that are critically linked to the pathophysiology of salt-sensitivity and hypertension.

\section{ANG II, NO and $\mathrm{O}_{2}^{-}$interactions and renal function}

Several mechanisms of the interaction between ANG II, $\mathrm{NO}$ and $\mathrm{O}_{2}^{-}$that are involved in the regulation of kidney function have been demonstrated in many studies (Wilcox 2005, Patzak and Persson 2007). Although direct acute effect of ANG II on renal hemodynamic and excretory function is well known, new findings have been described when $\mathrm{NO}$ or $\mathrm{O}_{2}^{-}$is pharmacologically interfered acutely. In rats (Lopez et al. 2003), it has been shown that acute ANG II infusion into the kidney caused a dosedependent reduction in glomerular filtration rate (GFR) and NO level in the renal cortex. Moreover, the dose of ANG II administered into the dog kidney, that unaffected GRF under intact conditions, reduced GFR after NOS inhibition (Majid et al. 2005). This response was greatly attenuated by concomitant administration of a $\mathrm{O}_{2}{ }^{-}$ scavenger, tempol, or Nox inhibitor, apocynin (Lopez et al. 2003, Majid et al. 2005). These data clearly indicate an interactive role of ANG II, NO and $\mathrm{O}_{2}^{-}$in the 
regulation of GFR, where NO displays protective properties against vasoconstrictors to maintain GFR. Furthermore, the sodium retaining effect of acute ANG II infusion was also influenced by concomitant $\mathrm{O}_{2}{ }^{-}$ generation (Lopez et al. 2003) and such effects were greatly accelerated under the conditions of NO blockade in dogs (Majid et al. 2005). Acute systemic infusion of ANG II in mice lacking catalytic subunit of Nox, gp91 ${ }^{\text {phox }}$ (gp91 ${ }^{\text {phox }} \mathrm{KO}$ ), which exhibit lower production of $\mathrm{O}_{2}^{-}$, caused a lesser degree of decreases in renal blood flow (RBF) and increases in renal vascular resistance (RVR) compared to wild-type mice (Haque and Majid 2004). These observations demonstrate that the acute renal effects of ANG II are enhanced by an increased Noxderived $\mathrm{O}_{2}^{-}$production, particularly under the conditions of NO deficiency, and they can be partially attenuated by the use of $\mathrm{O}_{2}^{-}$scavengers or Nox inhibitor and also in gp91 ${ }^{\text {phox }}$ KO mice.

These in vivo observations are well supported by in vitro studies testing the resistance and responsiveness of afferent and efferent arterioles, tubuloglomerular feedback (TGF) mechanisms and tubular transport in the isolated tubules. Glomerular arterioles account for the major part of renal vascular resistance and thus play important role in the control of RBF and GFR. It has been clearly demonstrated that constrictor responses of glomerular arterioles to ANG II were increased after NOS blockade (Ikenaga et al. 1996a). These responses to ANG II are also attenuated by addition of superoxide dismutase or tempol to this preparation (Schoonmaker et al. 2000, Ozawa et al. 2004). Thus $\mathrm{O}_{2}^{-}$appears to be partially responsible for ANG II-induced constriction of that vascular segment. Moreover, NO is diminished by increasing $\mathrm{O}_{2}^{-}$and thus vasoconstriction can be further enhanced (Wilcox and Welch 2000). These interactions directly modulate the TGF mechanism and tubular function in nephrons. Although ANG II is essential for TGR responsiveness (Ikenaga et al. 1996b, Schnermann et al. 1997), its increased production leads to the exaggerated TGF responses in hypertensive animals (Huang et al. 1988, Brannstrom et al. 1999, Welch et al. 2000). Furthermore, $\mathrm{O}_{2}{ }^{-}$enhances the basal TGF response and limits NO signaling from the macula densa. On the other hand, NO particularly derived from the macula densa inhibits TGF to antagonize enhanced ANG II and $\mathrm{O}_{2}^{-}$effects (Braam and Koomans 1995, Ichihara and Navar 1999, Wilcox and Welch 2000, Wang et al. 2002). The role of ANG II and NO interaction in the regulation of tubular sodium transport within nephron segments has been studied conclusively (Wang and Giebisch 1996, Dickhout et al. 2002, Mori and Cowley 2003, Zhang and Edwards 2007, Silva and Garvin 2008) as these substances counteract each other. Significant finding has been made by Garvin's group when a direct stimulatory effect of $\mathrm{O}_{2}^{-}$on sodium transport in thick ascending limb of loop of Henle has been found. And this stimulatory $\mathrm{O}_{2}{ }^{-}$ effect on tubules is also counteracted by NO (Ortiz and Garvin 2002a, 2002b, Juncos et al. 2006). Thus it is obvious that these mechanisms play an important role in the regulation of sodium excretion and may contribute in the development of salt-sensitivity and hypertension. This notion is further supported by observations that high salt intake induces production of $\mathrm{NO}$ as well as $\mathrm{O}_{2}^{-}$in the glomerular arteries, macula densa and tubules where they modulate physiological function of the kidney (Ortiz et al. 2003, Varela et al. 2004, Abe et al. 2006).

Collectively, these in vivo and in vitro studies propose new insights into the involvement of ANG II, $\mathrm{NO}$ and $\mathrm{O}_{2}^{-}$interactions in the regulation of renal hemodynamics and tubular function and suggest possible mechanisms that may contribute to the development of salt-sensitivity and hypertension (Fig. 1).

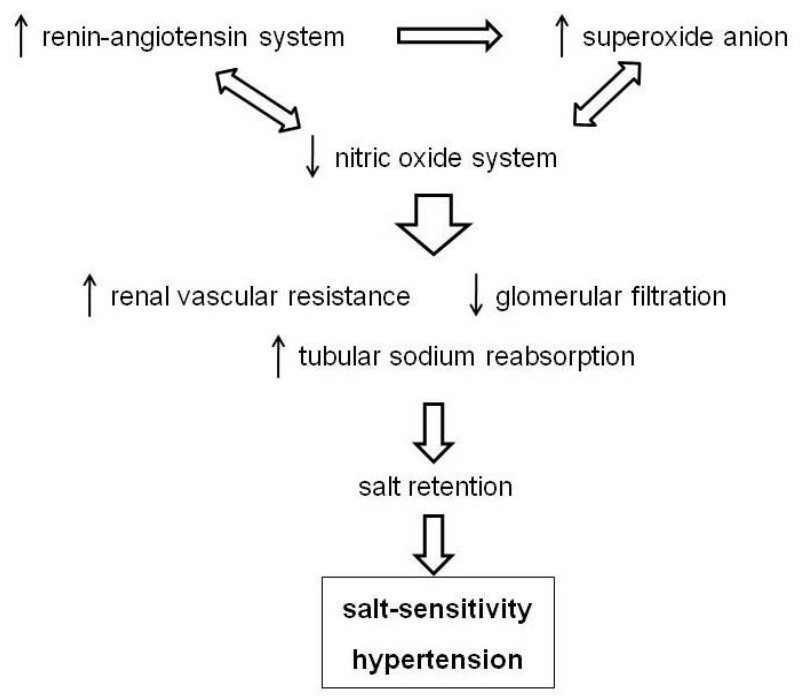

Fig. 1. Pathophysiological impact of the imbalance between renin-angiotensin system, superoxide anion and nitric oxide in the kidney.

\section{Pathophysiological impact of RAS, NO and $\mathrm{O}_{2}^{-}$interactions in ANG II-dependent hypertension}

Many studies have confirmed the prominent importance of RAS in the pathophysiology of 
hypertension (Reckelhoff and Romero 2003, Navar 2004). Hypertension induced by chronic infusion of subpressor ANG II dose is a simple model which does not have elevated circulating or tissue renin activity. Although the enhanced plasma and mainly kidney ANG II levels has been confirmed in this model, renal hemodynamic and tubular function are maintained at relatively normal range or can be just slightly reduced (Von Thun et al. 1994, Wang et al. 1997, Kopkan et al. 2006). This observation strongly suggests that counteracting renoprotective mechanisms are activated. As seen in ANG II-induced hypertensive rats, NO partially counteracts the vasoconstrictor influence of elevated ANG II levels to maintain renal hemodynamics (Chin et al. 1998, Nishiyama et al. 2001). In addition, the exogenous L-arginine can significantly blunt angiotensin II-dependent hypertension and associated renal damage by increasing NO bioavailability in hypertensive animals (Rajapakse et al. 2008). The relation between high salt intake and blood pressure responses to chronic ANG II administration were also evaluated in rats (Sasser et al. 2002, Pech et al. 2006). As high salt intake exaggerated ANG II-induced increase in blood pressure, this model of hypertension exhibits an obvious salt-sensitivity. Moreover, the development of salt-sensitive hypertension has been demonstrated after transient exposure to ANG II in rats with progressive organ damage (Lombardi et al. 1999, Rodriguez-Iturbe et al. 2001).

There is a clear link between oxidative stress and the development of ANG II-induced hypertension (Wang et al. 2001, Reckelhoff and Romero 2003), but the exact mechanisms are not yet fully understood. It has been shown that production of $\mathrm{O}_{2}^{-}$is enhanced via $\mathrm{NAD}(\mathrm{P}) \mathrm{H}$ oxidase. Moreover, defense antioxidative enzymes (superoxide dismutase, catalase and gluthatione peroxidase) in the kidney were reduced during ANG II exposure (Cifuentes et al. 2000, Chabrashvili et al. 2003, Welch et al. 2005, Pech et al. 2006). The development of hypertension induced by chronic low-dose infusion of ANG II was shown to be attenuated by chronic treatment with tempol in mice and rats (Kawada et al. 2002, Welch et al. 2005). An enhanced ROS production during chronic ANG II administration might not be only involved in the progression of organ damage. As it has been demonstrated that an enhanced $\mathrm{O}_{2}^{-}$activity mediates acute renal responses to ANG II (Lopez et al. 2003, Haque and Majid 2004, Majid et al. 2005), the possible role of enhanced $\mathrm{O}_{2}^{-}$generation in the regulation of renal function has examined in ANG II-induced hypertensive rats (Kopkan et al. 2006). This study showed that acute tempol infusion into the renal artery in anesthetized rats increased RBF, GFR and $\mathrm{U}_{\mathrm{Na}} \mathrm{V}$ in hypertensive rats, but not in normotensive rats, implying that enhanced generation of $\mathrm{O}_{2}^{-}$modulates renal hemodynamic and excretory function leading to sodium retention in this model.

In the transgenic rat model of ANG II-dependent hypertension with constitutive mouse renin gene expression (TGR) which exhibits increased circulating as well as tissue ANG II levels and also oxidative stress since prehypertensive phase (Kopkan et al. 2005, Vaněčková et al. 2005), it has been observed that tempol administered directly into the renal artery acutely increased renal plasma flow (RPF) and GFR in these prehypertensive animals. Moreover, NOS inhibitor, nitro-L-arginine methylester (LNAME) caused greater decreases in RBF and sodium excretion in prehypertensive TGR compared to agematched control rats and these responses to L-NAME were abolished by co-administration of tempol (Kopkan et al. 2007). These data suggest that renal function is modulated by enhanced $\mathrm{O}_{2}^{-}$generation induced by ANG II in prehypertensive TGR and further support the notion that NO serves a protective role maintaining normal renal function in this model. To examine the role of this enhanced O2- generation in the pathophysiology of hypertension in TGR, chronic antioxidant treatment was applied during the development of hypertension in these animals (Kopkan et al. 2009). However, despite of reduction in oxidative stress by tempol and apocynin administration in TGR, hypertension was not attenuated in this model. These data suggest that the markedly enhanced ANG II activity is almost entirely responsible for the development of hypertension with a negligible contribution of oxidative stress to the pathophysiology of hypertension in this model of ANG II-dependent hypertension (Kopkan et al. 2009).

In TGR, high-salt diet induced significant increases in blood pressure at all ages when compared with age-matched TGR fed normal-salt diet (Husková et al. 2006). Interestingly, salt-sensitive responses in early stages of hypertension were more pronounced in female than in male TGR. On the other hand, salt restriction led to lower progression of hypertension in both female and male TGR. This observation cannot be explained just by unresponsiveness of RAS activity to various levels of salt intake in these animals and thus other unknown mechanism needs to be considered (Husková et al. 2007). These studies indicate a strong salt-sensitive component 
of hypertension with unanticipated sexual dimorphism. However, the exact role of the interaction between ANG II, NO and $\mathrm{O}_{2}^{-}$in the salt-sensitivity remains to be clarified in this model.

Another important model of ANG II-dependent hypertension is the two-kidney, one-clip (2K1C) Goldblatt model in which hypertension is induced by unilateral stenosis of the renal artery (Welch et al. 2003, Navar 2004, Červenka et al. 2008). The reduced renal perfusion pressure stimulates renin release from the clipped kidney triggering a whole RAS cascade with a slow progression of hypertension. Similarly to the previous models of ANG IIdependent hypertension, the augmented RAS activity leads to the induction of oxidative stress that may be involved in the pathophysiology of hypertension in this model (Lerman et al. 2001). This was further supported by acute administration of tempol that reduced RVR and increased RPF, GFR and sodium excretion in both clipped and nonclipped kidney (Guron et al. 2006). Moreover, chronic treatment with tempol reduced blood pressure and also improved renal function in the clipped kidney (Welch at el. 2003). A protective role of NO in the kidney has been also suggested in this model where enhanced NO release buffers ANG II-induced contraction of isolated afferent arteriole from the nonclipped kidney of 2K1C hypertensive rats (Helle et al. 2009). It seems that NO protective mechanism might be impaired in 2K1C hypertensive rats (Sánchez-Mendoza et al. 1998, Červenka et al. 2008). The administration of L-arginine, as a substrate for NO generation, has been shown to attenuate hypertension in 2K1C rats suggesting that $\mathrm{NO}$ production is insufficient in this model (Abreu et al. 1999). Moreover, treatment with losartan prevented increased vascular responses to ANG II, and this effect was associated with a restoration of NOS activity and NO release (Martinez et al. 2002). These data suggest that ANG II reduces NOS activity directly or via enhanced ROS production blunting vascular and renal effects of NO during the development of renovascular hypertension. Given together, these investigations collectively help in understanding these interactions and their possible involvement in the pathophysiology of hypertension.

\section{Pathophysiological impact of RAS, NO and $\mathrm{O}_{2}^{-}$interactions in salt-induced models of hypertension}

Dahl salt-sensitive rats exhibit progressive increases in arterial pressure in response to high salt intake leading to the endothelial dysfunction, inflammation and renal damage. An impaired NO system and oxidative stress have been suggested to significantly contribute to the development of hypertension in this model (Tan et al. 2000, Zicha et al. 2001, Mori et al. 2007, Zhou et al. 2009). However, exaggerated local RAS activity is also involved in the pathophysiological processes. Although Dahl salt-sensitive rats have low renin level and high salt intake suppresses plasma ANG II, it has been observed that kidney ANG II level is not decreased by high salt (Kobori et al. 2003). Moreover, high salt intake increases renal angiotensinogen level in Dahl salt-sensitive rats. This paradoxical enhancement may be an important contributor to the salt-sensitivity in this model (Kobori et al. 2003). It has been also indicated that sympathetic hyperactivity in Dahl salt-sensitive rats plays a major role in the maintenance of salt-sensitive hypertension (Zicha et al. 2001). These sympathetic responses to high salt intake are also closely associated with enhanced RAS and $\mathrm{O}_{2}^{-}$activity and $\mathrm{NO}$ deficiency and these interactions may influence renal function in hypertensive animals. There is a good agreement between these results and studies indicating that RAS inhibition attenuates hypertension, endothelial dysfunction and renal damage in Dahl rats (Tian et al. 2006, Liang and Leenen 2008, Zhou et al. 2009). Similar protective effects have been shown during antioxidant treatments, when renal function was improved in these hypertensive rats (Tomohiro et al. 1997, Tian et al. 2008).

In other salt-induced model of hypertension deoxycorticosterone acetate (DOCA) rats - oxidative stress, insufficient NO production and local ANG II seem to play a role in the development of hypertension and impaired organ function (K-Laflamme et al. 1998, Shelat et al. 1999, Rhaleb et al. 2001, Beswick et al. 2001a, Sullivan et al. 2002, Obst et al. 2004, Erdely et al. 2007). Similarly to Dahl rats, antioxidant treatment or RAS inhibition attenuated hypertension and organ damage in DOCA-salt rats and improves endothelial dysfunction by increased NO generation in these hypertensive animals (Gross et al. 1999, Beswick et al. 2001a, 2001b, Xu et al. 2002, Ghosh et al. 2004). It could be argued that blood pressure lowering effect of $\mathrm{O}_{2}^{-}$scavengers such as tempol might be due to inhibition of increased sympathetic activity in DOCA rats. However, it was also demonstrated that SOD inhibition enhancing $\mathrm{O}_{2}^{-}$level caused stimulation of renal sympathetic activity and tempol ameliorated this effect (Shokoji et al. 2004), indicating that tempol-induced inhibition of sympathetic 
activity could be related to its ability to scavenge $\mathrm{O}_{2}^{-}$. In DOCA rats, it has been observed that NO plays a protective role against hypertensive DOCA effect, as orally administered L-NAME induced a further increase in blood pressure (Alvarez et al. 2000). These results suggest that NOS inhibition may also affect sodium retention induced by DOCA and, therefore, increases blood pressure in this model. Overall, this provides further evidence that ANG II, NO and $\mathrm{O}_{2}^{-}$interactions and their impact on regulation of renal function contribute to the development of salt-sensitive hypertension.

\section{Pathophysiological impact of RAS, NO and $\mathrm{O}_{2}^{-}$interactions in NO-deficient form of hypertension}

The most conclusive evidence for the essential role of $\mathrm{NO}$ in the regulation of blood pressure and organ function was obtained from a model using pharmacological inhibition of NO production that primarily targets the constitutive eNOS as a major source of NO under normal condition. Although this is a simple experimental model, it reveals in fact very complex mechanisms that contribute to the pathophysiology of NO-deficient hypertension (Zatz and Baylis 1998). Acute cardiovascular and renal effects of NOS inhibition have been studied intensively in many in vivo and in vitro preparations, as mentioned above. In conscious animals, chronic administration of nonselective NOS inhibitors produced sustained hypertension, increased vascular resistance and an impairment of organ function including the kidney (Baylis et al. 1992, Lahera et al. 1992, Tolins and Shultz 1994, Kopkan and Majid 2006). An activation of RAS and sympathetic tone may also account, at least in part, for the vasoconstrictor activity after NOS inhibition (Fortepiani et al. 1999, Pecháňová et al. 2004, Zicha et al. 2006). Moreover, an enhanced $\mathrm{O}_{2}^{-}$activity has been indicated as an important contributor for the pathophysiology of NO-deficient form of hypertension (Usui et al. 1999, Rauchová et al. 2005). Although an exact explanation for the exaggerated activities of vasoconstrictor systems during NO inhibition is still indefinite, this model could afford more pathophysiological mechanisms of the imbalance between those vasoactive substances than other hypertensive models.

Previous observations have shown that NO not only counteracts the vascular effects of vasoconstrictors, but it exhibits crucial properties in the maintenance of sodium and extracellular fluid homeostasis. This notion has been further supported by observation that NOdeficient hypertensive animals evidently exhibit saltsensitivity (Tolins and Shultz 1994, Kopkan and Majid 2005) leading to the progression of renal injury in this model (Yamada et al. 1996, Graciano et al. 2004). Interestingly, after 3 week exposure to L-NAME and the 1 week washout period, a salt-sensitive state has been still observed in rats (Quiroz et al. 2001). This founding was explained by irreversible renal damage and inflammation after prolong NO blockade. Furthermore, it was observed in NO-deficient animals, that this exaggerated hypertensive response to high salt intake was abolished by concomitant administration of tempol with L-NAME (Kopkan and Majid 2005). These data indicate that $\mathrm{O}_{2}{ }^{-}$ contributes to the development of salt-sensitivity, which is involved in the pathophysiology of NO-deficient hypertension. The pathophysiological role of enhanced $\mathrm{O}_{2}^{-}$activity in the kidney in salt-sensitive responses was more than evident in this model. Indeed, acute treatment with an $\mathrm{O}_{2}^{-}$scavenger, tempol, increased RBF, GFR, and urinary sodium excretion in L-NAME-induced hypertensive rats (Kopkan and Majid 2006). Taken together, these results demonstrate that enhanced $\mathrm{O}_{2}{ }^{-}$ activity under the conditions of $\mathrm{NO}$ deficiency modulates renal hemodynamics and excretory function, which contribute to the development of salt-sensitivity and hypertension induced by chronic NOS inhibition.

Although specific contributions of particular NOS isoforms in the regulation of renal function and blood pressure have been studied in many models of hypertension, acute and chronic administration of the potentially selective inhibitors for nNOS or iNOS have yielded inconclusive results that were mostly limited by missing selective eNOS inhibition (Ollerstam et al. 1997, Mattson et al. 1998). However, studies in genetically modified mice strongly support the notion that eNOS isoform is a predominant and essential source of NO maintaining several physiological processes in the body (Ortiz and Garvin 2003). It has been observed that knockout mice lacking the gene for the eNOS exhibit higher blood pressure and impaired vasodilator responses (Huang et al. 1995, Faraci et al. 1998), whereas deletion of the genes encoding the nNOS or iNOS isoforms did not significantly alter cardiovascular system (Ortiz and Garvin 2003). In the mouse kidney, NO derived from eNOS regulates renal hemodynamics (Mattson and Meister 2005, Patzak et al. 2008), but it remains to be 
determined if an increased salt and fluid absorption by the kidney may be involved in the hypertension exhibited by eNOS-deficient mice. Although nNOS and iNOS may partially compensate deficient production of NO in these mice (Mattson and Meister 2006, Patzak et al. 2008), the study by Ortiz et al. (2003) suggested that eNOS mediates NO production and thus regulates sodium chloride transport in thick ascending limb. This transport mechanism is impaired in eNOS deficient mice, in which it can be reversed by eNOS gene transfer to the thick ascending limb (Ortiz et al. 2003). These data indicate that genetic deletion of eNOS is not compensated for the thick ascending limb by other NOS isoforms. Thus an increased blood pressure response to a high-salt diet that has been observed in eNOS-deficient mice (Leonard et al. 2006) is likely promoted by reduced production of NO in the tubules. It remains to be resolved whether other mechanisms such as increased $\mathrm{O}_{2}^{-}$may contribute in the salt-sensitivity and hypertension in this mouse model.

\section{Conclusions and Perspectives}

This minireview demonstrates the important interactive role between $\mathrm{RAS}, \mathrm{O}_{2}^{-}$and $\mathrm{NO}$ in the regulation of renal hemodynamics and tubular sodium excretion and its impact on blood pressure supporting the hypothesis that imbalance between these substances may contribute to the development of salt-sensitivity and hypertension (Fig. 1). These observations suggest that the activation of RAS, which is associated with an enhanced $\mathrm{O}_{2}^{-}$activity, causes reduction of NO availability leading to the disparity between oxidative and antioxidative mechanisms in the tissues, which is involved in many pathophysiological processes in the body. It should be emphasized that further experiments are needed to characterize and delineate these interactions at the enzymatic level of the production of vasoactive substances such as ANG II, oxidative and nitrosative radicals in normal conditions as well as during the development of salt-sensitive hypertension. These new findings would increase our understanding of physiological as well as pathophysiological processes of many cardiovascular and renal diseases.

\section{Conflict of Interest}

There is no conflict of interest.

\section{Acknowledgements}

We acknowledge the support provided by the grants NS/9699-4 and KJB502030801 and by financial support from the Institute for Clinical and Experimental Medicine (\#MZO 00023001) and Center for Cardiovascular Research (\#1M6798582302). The authors gratefully thank Dr. Josef Zicha, Institute of Physiology of the ASCR, for his valuable comments and suggestions during preparation of this manuscript.

\section{References}

ABE M, O'CONNOR P, KALDUNSKI M, LIANG M, ROMAN RJ, COWLEY AW JR: Effect of sodium delivery on superoxide and nitric oxide in the medullary thick ascending limb. Am J Physiol 291: F350-F357, 2006.

ABREU GR, FUTURO-NETO HA, CABRAL AM, VASQUEZ EC: L-arginine restores the effect of ouabain on baroreceptor activity and prevents hypertension. Hypertension 34: 729-732, 1999.

ALVAREZ G, OSUNA A, WANGENSTEEN R, VARGAS F: Interaction between nitric oxide and mineralocorticoids in the long-term control of blood pressure. Hypertension 35: 752-757, 2000.

BACHMANN S, BOSSE HM, MUNDEL P: Topography of nitric oxide synthesis by localizing constitutive NO synthases in mammalian kidney. Am J Physiol 268: F885-F898, 1995.

BARRI YM, WILCOX CS: Salt intake determines the renal response to L-arginine infusion in normal human subjects. Kidney Int 53: 1299-1304, 1998.

BAYLIS C, MITRUKA B, DENG A: Chronic blockade of nitric oxide synthesis in the rat produces systemic hypertension and glomerular damage. J Clin Invest 90: 278-281, 1992.

BESWICK RA, DORRANCE AM, LEITE R, WEBB RC: NADH/NADPH oxidase and enhanced superoxide production in the mineralocorticoid hypertensive rat. Hypertension 38: 1107-1111, 2001b.

BESWICK RA, ZHANG H, MARABLE D, CATRAVAS JD, HILL WD, WEBB RC: Long-term antioxidant administration attenuates mineralocorticoid hypertension and renal inflammatory response. Hypertension 37 : 781-786, 2001a. 
BRAAM B, KOOMANS HA: Nitric oxide antagonizes the actions of angiotensin II to enhance tubuloglomerular feedback responsiveness. Kidney Int 48: 1406-1411, 1995.

BRANNSTROM K, MORSING P, ARENDSHORST WJ: Candesartan normalizes exaggerated tubuloglomerular feedback activity in young spontaneously hypertensive rats. $J$ Am Soc Nephrol 10 (Suppl 11): S213-S219, 1999.

ČERVENKA L, VANĚČKOVÁ I, HUSKOVÁ Z, VAŇOURKOVÁ Z, ERBANOVÁ M, THUMOVÁ M, ŠKAROUPKOVÁ P, OPOČENSKÝ M, MALÝ J, CHÁBOVÁ VC, TESǍ̌ V, BÜRGELOVÁ M, VIKLICKÝ O, TEPLAN V, ŽELÍZKO M, KRAMER HJ, NAVAR LG: Pivotal role of angiotensin II receptor subtype $1 \mathrm{~A}$ in the development of two-kidney, one-clip hypertension: study in angiotensin II receptor subtype 1A knockout mice. J Hypertens 26: 1379-1389, 2008.

CHABRASHVILI T, KITIYAKARA C, BLAU J, KARBER A, ASLAM S, WELCH WJ, WILCOX CS: Effects of ANG II type 1 and 2 receptors on oxidative stress, renal NADPH oxidase, and SOD expression. Am J Physiol 285: R117-R124, 2003.

CHIN SY, WANG CT, MAJID DS, NAVAR LG: Renoprotective effects of nitric oxide in angiotensin II-induced hypertension in the rat. Am J Physiol 274: F876-F882, 1998.

CHIN SY, PANDEY KN, SHI SJ, KOBORI H, MORENO C, NAVAR LG: Increased activity and expression of $\mathrm{Ca}^{2+}-$ dependent NOS in renal cortex of ANG II-infused hypertensive rats. Am J Physiol 277: F797-F804, 1999.

CIFUENTES ME, REY FE, CARRETERO OA, PAGANO PJ: Upregulation of p67(phox) and gp91(phox) in aortas from angiotensin II-infused mice. Am J Physiol 279: H2234-H2240, 2000.

DICKHOUT JG, MORI T, COWLEY AW JR: Tubulovascular nitric oxide crosstalk: buffering of angiotensin IIinduced medullary vasoconstriction. Circ Res 91: 487-493, 2002.

ERDELY A, FRESHOUR G, TAIN YL, ENGELS K, BAYLIS C: DOCA/NaCl-induced chronic kidney disease: a comparison of renal nitric oxide production in resistant and susceptible rat strains. Am J Physiol 292: F192F196, 2007.

FARACI FM, SIGMUND CD, SHESELY EG, MAEDA N, HEISTAD DD: Responses of carotid artery in mice deficient in expression of the gene for endothelial NO synthase. Am J Physiol 274: H564-H570, 1998.

FORTEPIANI LA, RODRIGO E, ORTÍZ MC, CACHOFEIRO V, ATUCHA NM, RUILOPE LM, LAHERA V, GARCÍA-ESTAÑ J: Pressure natriuresis in nitric oxide-deficient hypertensive rats: effect of antihypertensive treatments. J Am Soc Nephrol 10: 21-27, 1999.

FRANCO V, OPARIL S: Salt sensitivity, a determinant of blood pressure, cardiovascular disease and survival. $J \mathrm{Am}$ Coll Nutr 25 (Suppl 3): 247S-255S, 2006.

GHOSH M, WANG HD, MCNEILL JR: Role of oxidative stress and nitric oxide in regulation of spontaneous tone in aorta of DOCA-salt hypertensive rats. Br J Pharmacol 141: 562-573, 2004.

GILL PS, WILCOX CS: NADPH oxidases in the kidney. Antioxid Redox Signal 8: 1597-1607, 2006.

GRACIANO ML, CAVAGLIERI RDE C, DELLE H, DOMINGUEZ WV, CASARINI DE, MALHEIROS DM, NORONHA IL: Intrarenal Renin-Angiotensin system is upregulated in experimental model of progressive renal disease induced by chronic inhibition of nitric oxide synthesis. J Am Soc Nephrol 15: 1805-1815, 2004.

GROSS V, SCHNEIDER W, SCHUNCK WH, MERVAALA E, LUFT FC: Chronic effects of lovastatin and bezafibrate on cortical and medullary hemodynamics in deoxycorticosterone acetate-salt hypertensive mice. J Am Soc Nephrol 10: 1430-1439, 1999.

GURON GS, GRIMBERG ES, BASU S, HERLITZ H: Acute effects of the superoxide dismutase mimetic tempol on split kidney function in two-kidney one-clip hypertensive rats. J Hypertens 24: 387-394, 2006.

GUYTON AC, COLEMAN TG, COWLEY AV JR, SCHEEL KW, MANNING RD JR, NORMAN RA JR: Arterial pressure regulation. Overriding dominance of the kidneys in long-term regulation and in hypertension. $A m J$ Med 52: 584-594, 1972.

HADDY FJ: Role of dietary salt in hypertension. Life Sci 79: 1585-1592, 2006.

HALL JE, GUYTON AC, SMITH MJ JR, COLEMAN TG: Blood pressure and renal function during chronic changes in sodium intake: role of angiotensin. Am J Physiol 239: F271-F280, 1980. 
HANNKEN T, SCHROEDER R, STAHL RA, WOLF G: Angiotensin II-mediated expression of p27Kip1 and induction of cellular hypertrophy in renal tubular cells depend on the generation of oxygen radicals. Kidney Int 54: 1923-1933, 1998.

HAQUE MZ, MAJID DSA: Assessment of renal functional phenotype in mice lacking gp91phox subunit of NAD(P)H oxidase. Hypertension 43: 335-340, 2004.

HELLE F, HULTSTRÖM M, SKOGSTRAND T, PALM F, IVERSEN BM: Angiotensin II-induced contraction is attenuated by nitric oxide in afferent arterioles from the nonclipped kidney in $2 \mathrm{~K} 1 \mathrm{C}$. Am J Physiol 296: F78F86, 2009.

HERRERA M, SILVA G, GARVIN JL: A high-salt diet dissociates NO synthase-3 expression and NO production by the thick ascending limb. Hypertension 47: 95-101, 2006.

HUANG PL, HUANG Z, MASHIMO H, BLOCH KD, MOSKOWITZ MA, BEVAN JA, FISHMAN MC. Hypertension in mice lacking the gene for endothelial nitric oxide synthase. Nature 377: 239-242, 1995.

HUANG WC, BELL PD, HARVEY D, MITCHELL KD, NAVAR LG: Angiotensin influences on tubuloglomerular feedback mechanism in hypertensive rats. Kidney Int 34: 631-637, 1988.

HUSKOVÁ Z, KRAMER HJ, VAŇOURKOVÁ Z, ČERVENKA L: Effects of changes in sodium balance on plasma and kidney angiotensin II levels in anesthetized and conscious Ren-2 transgenic rats. J Hypertens 24: 517-527, 2006.

HUSKOVÁ Z, KRAMER H, VAŇOURKOVÁ Z, THUMOVÁ M, MALÝ J, OPOCENSKÝ M, ŠKAROUPKOVÁ P, KOLSKÝ A, VERNEROVÁ Z, ČERVENKA L: Effects of dietary salt load and salt depletion on the course of hypertension and angiotensin II levels in male and female heterozygous Ren-2 transgenic rats. Kidney Blood Press Res 30: 45-55, 2007.

ICHIHARA A, NAVAR LG: Neuronal NOS contributes to biphasic autoregulatory response during enhanced TGF activity. Am J Physiol 277: F113-F120, 1999.

IKENAGA H, FALLET RW, CARMINES PK: Basal nitric oxide production curtails arteriolar vasoconstrictor responses to ANG II in rat kidney. Am J Physiol 271: F365-F373, 1996a.

IKENAGA H, FALLET RW, CARMINES PK: Contribution of tubuloglomerular feedback to renal arteriolar angiotensin II responsiveness. Kidney Int 49: 34-39, $1996 \mathrm{~b}$.

JACKSON CA, NAVAR LG: Arterial pressure and renal function in two-kidney, one clip Goldblatt hypertensive rats maintained on a high-salt intake. J Hypertens 4: 215-221, 1986.

JUNCOS R, HONG NJ, GARVIN JL: Differential effects of superoxide on luminal and basolateral $\mathrm{Na}^{+} / \mathrm{H}^{+}$exchange in the thick ascending limb. Am J Physiol 290: R79-R83, 2006.

KAWADA N, IMAI E, KARBER A, WELCH WJ, WILCOX CS: A mouse model of angiotensin II slow pressor response: Role of oxidative stress. J Am Soc Nephrol 13: 2860-2868, 2002.

KITIYAKARA C, CHABRASHVILI T, CHEN Y, BLAU J, KARBER A, ASLAM S, WELCH WJ, WILCOX CS: Salt intake, oxidative stress, and renal expression of NADPH oxidase and superoxide dismutase. J Am Soc Nephrol 14: 2775-2782, 2003.

K-LAFLAMME A, OSTER L, CARDINAL R, DE CHAMPLAIN J: Role of NO and angiotensin II in the early development of endothelial functions impairment and cardiac hypertrophy in deoxycorticosterone acetate-salt hypertension. Can J Physiol Pharmacol 76: 665-675, 1998.

KOBORI H, NISHIYAMA A, ABE Y, NAVAR LG: Enhancement of intrarenal angiotensinogen in Dahl salt-sensitive rats on high salt diet. Hypertension 41: 592-597, 2003.

KOPKAN L, MAJID DS: Superoxide contributes to development of salt sensitivity and hypertension induced by nitric oxide deficiency. Hypertension 46: 1026-1031, 2005.

KOPKAN L, MAJID DS: Enhanced superoxide activity modulates renal function in NO-deficient hypertensive rats. Hypertension 47: 568-572, 2006.

KOPKAN L, KRAMER HJ, HUSKOVÁ Z, VAŇOURKOVÁ Z, ŠKAROUPKOVÁ P, THURMOVÁ M, ČERVENKA L: The role of intrarenal angiotensin II in the development of hypertension in Ren-2 transgenic rats. J Hypertens 23: 1531-1539, 2005.

KOPKAN L, CASTILLO A, NAVAR LG, MAJID DS: Enhanced superoxide generation modulates renal function in angiotensin II-induced hypertensive rats. Am J Physiol 290: F80-F86, 2006. 
KOPKAN L, HUSKOVÁ Z, VAŇOURKOVÁ Z, THUMOVÁ M, ŠKAROUPKOVÁ P, ČERVENKA L, MAJID DS: Superoxide and its interaction with nitric oxide modulates renal function in prehypertensive Ren-2 transgenic rats. J Hypertens 25: 2257-2265, 2007.

KOPKAN L, HUSKOVÁ Z, VAŇOURKOVÁ Z, THUMOVÁ M, ŠKAROUPKOVÁ P, MALÝ J, KRAMER HJ, DVOǨÁK P, ČERVENKA L: Reduction of oxidative stress does not attenuate the development of angiotensin II-dependent hypertension in Ren-2 transgenic rats. Vascul Pharmacol 51: 175-181, 2009.

LAHERA V, SALAZAR J, SALOM MG, ROMERO JC: Deficient production of nitric oxide induces volumedependent hypertension. J Hypertens 10 (Suppl 1): S173-S177, 1992.

LEONARD AM, CHAFE LL, MONTANI JP, VAN VLIET BN: Increased salt-sensitivity in endothelial nitric oxide synthase-knockout mice. Am J Hypertens 19: 1264-1269, 2006.

LERMAN LO, NATH KA, RODRIGUEZ-PORCEL M, KRIER JD, SCHWARTZ RS, NAPOLI C, ROMERO JC: Increased oxidative stress in experimental renovascular hypertension. Hypertension 37: 541-546, 2001.

LIANG B, LEENEN FH: Prevention of salt-induced hypertension and fibrosis by AT1-receptor blockers in Dahl S rats. J Cardiovasc Pharmacol 51: 457-466, 2008.

LOMBARDI D, GORDON KL, POLINSKY P, SUGA S, SCHWARTZ SM, JOHNSON RJ: Salt-sensitive hypertension develops after short-term exposure to angiotensin II. Hypertension 33: 1013-1019, 1999.

LOPEZ B, SALOM MG, ARREGUI B, VALERO F, FENOY FJ: Role of superoxide in modulating the renal effects of angiotensin II. Hypertension 42: 1150-1156, 2003.

MAJID DS, NAVAR LG: Nitric oxide in the control of renal hemodynamics and excretory function. Am J Hypertens 14 (Suppl 3): 74S-82S, 2001.

MAJID DS, NISHIYAMA A: Nitric oxide blockade enhances renal responses to superoxide dismutase inhibition in dogs. Hypertension 39: 293-297, 2002.

MAJID DS, NISHIYAMA A, JACKSON KE, CASTILLO A: Superoxide scavenging attenuates renal responses to ANG II during nitric oxide synthase inhibition in anesthetized dogs. Am J Physiol 288: F412-F419, 2005.

MAKINO A, SKELTON MM, ZOU AP, ROMAN RJ, COWLEY AW JR: Increased renal medullary oxidative stress produces hypertension. Hypertension 39: 667-672, 2002.

MANCIA G, DE BACKER G, DOMINICZAK A, CIFKOVA R, FAGARD R, GERMANO G, GRASSI G, HEAGERTY AM, KJELDSEN SE, LAURENT S, NARKIEWICZ K, RUILOPE L, RYNKIEWICZ A, SCHMIEDER RE, BOUDIER HA, ZANCHETTI A: 2007 ESH-ESC Practice Guidelines for the Management of Arterial Hypertension: ESH-ESC Task Force on the Management of Arterial Hypertension. J Hypertens 25 : 1751-1762, 2007.

MARTINEZ Y, MARTINEZ S, MEANEY A, MEANEY E, ESCALANTE B: Angiotensin II type 1 receptor blockade restores nitric oxide-dependent renal vascular responses in renovascular hypertension. $J$ Cardiovasc Pharmacol 40: 381-387, 2002.

MATTSON DL, HIGGINS DJ: Influence of dietary sodium intake on renal medullary nitric oxide synthase. Hypertension 27: 688-692, 1996.

MATTSON DL, MEISTER CJ: Renal cortical and medullary blood flow responses to L-NAME and ANG II in wildtype, nNOS null mutant, and eNOS null mutant mice. Am J Physiol 289: R991-R997, 2005.

MATTSON DL, MEISTER CJ: Sodium sensitivity of arterial blood pressure in L-NAME hypertensive but not eNOS knockout mice. Am J Hypertens 19: 327-329, 2006.

MATTSON DL, MAEDA CY, BACHMAN TD, COWLEY AW JR: Inducible nitric oxide synthase and blood pressure. Hypertension 31: 15-20, 1998.

MIDGLEY JP, MATTHEW AG, GREENWOOD CMT, LOGAN AG: Effect of reduced dietary sodium on blood pressure: a meta-analysis of randomized controlled trials. JAMA 275: 1590-1597, 1996.

MORENO C, LOPEZ A, LLINAS MT, RODRIGUEZ F, LOPEZ-FARRE A, NAVA E, SALAZAR FJ: Changes in NOS activity and protein expression during acute and prolonged ANG II administration. Am J Physiol 282: R31-R37, 2002.

MORI T, COWLEY AW JR: Angiotensin II-NAD(P)H oxidase stimulated superoxide modifies tubulovascular nitric oxide cross-talk in renal outer medulla. Hypertension 42: 588-593, 2003. 
MORI T, O'CONNOR PM, ABE M, COWLEY AW JR: Enhanced superoxide production in renal outer medulla of Dahl salt-sensitive rats reduces nitric oxide tubular-vascular cross-talk. Hypertension 49: 1336-1341, 2007.

NAVAR LG: The intrarenal renin-angiotensin system in hypertension. Kidney Int 65: 1522-1532, 2004.

NISHIYAMA A, FUJISAWA Y, FUKUI T, RAHMAN M, KONDO N, OGAWA Y, FANZHU L, GUOXING Z, KIMURA S, ABE Y: Role of nitric oxide in regional blood flow in angiotensin II-induced hypertensive rats. Hypertens Res 24: 421-427, 2001.

OBST M, GROSS V, BONARTSEV A, JANKE J, MULLER DN, PARK JK, KARGEL E, LUFT FC: Nitric oxide synthase expression in $\mathrm{AT}_{2}$ receptor-deficient mice after DOCA-salt. Kidney Int 65: 2268-2278, 2004.

OLLERSTAM A, PITTNER J, PERSSON AE, THORUP C: Increased blood pressure in rats after long-term inhibition of the neuronal isoform of nitric oxide synthase. J Clin Invest 99: 2212-2218, 1997.

ORTIZ PA, GARVIN JL: Interaction of $\mathrm{O}_{2}{ }^{-}$and $\mathrm{NO}$ in the thick ascending limb. Hypertension 39: 591-596, $2002 \mathrm{a}$.

ORTIZ PA, GARVIN JL: Superoxide stimulates $\mathrm{NaCl}$ absorption by the thick ascending limb. Am J Physiol 283: F957F962, 2002b.

ORTIZ PA, GARVIN JL: Cardiovascular and renal control in NOS-deficient mouse models. Am J Physiol 284: R628R638, 2003.

ORTIZ PA, HONG NJ, WANG D, GARVIN JL: Gene transfer of eNOS to the thick ascending limb of eNOS-KO mice restores the effects of L-arginine on $\mathrm{NaCl}$ absorption. Hypertension 42: 674-679, 2003.

OZAWA Y, HAYASHI K, WAKINO S, KANDA T, HOMMA K, TAKAMATSU I, TATEMATSU S, YOSHIOKA K, SARUTA T: Free radical activity depends on underlying vasoconstrictors in renal microcirculation. Clin Exp Hypertens 26: 219-229, 2004.

PATZAK A, PERSSON AE: Angiotensin II-nitric oxide interaction in the kidney. Curr Opin Nephrol Hypertens 16: 46-51, 2007.

PATZAK A, STEEGE A, LAI EY, BRINKMANN JO, KUPSCH E, SPIELMANN N, GERICKE A, SKALWEIT A, STEGBAUER J, PERSSON PB, SEELIGER E: Angiotensin II response in afferent arterioles of mice lacking either the endothelial or neuronal isoform of nitric oxide synthase. Am J Physiol 294: R429-R437, 2008.

PECH V, SIKKA SC, SINDHU RK, VAZIRI ND, MAJID DS: Oxidant stress and blood pressure responses to angiotensin II administration in rats fed varying salt diets. Am J Hypertens 19: 534-540, 2006.

PECHÁŇOVÁ O, DOBEŠOVÁ Z, ČEJKA J, KUNEŠ J, ZICHA J: Vasoactive systems in L-NAME hypertension: the role of inducible nitric oxide synthase. J Hypertens 22: 167-173, 2004.

POCH E, GONZÁLEZ D, GINER V, BRAGULAT E, COCA A, DE LA SIERRA A: Molecular basis of salt sensitivity in human hypertension. Evaluation of renin-angiotensin-aldosterone system gene polymorphisms. Hypertension 38: 1204-1209, 2001.

QUIROZ Y, PONS H, GORDON KL, RINCÓN J, CHÁVEZ M, PARRA G, HERRERA-ACOSTA J, GÓMEZGARRE D, LARGO R, EGIDO J, JOHNSON RJ, RODRÍGUEZ-ITURBE B: Mycophenolate mofetil prevents salt-sensitive hypertension resulting from nitric oxide synthesis inhibition. Am J Physiol 281: F38-F47, 2001.

RAJAGOPALAN S, KURZ S, MUNZEL T, TARPEY M, FREEMAN BA, GRIENDLING KK, HARRISON DG: Angiotensin II-mediated hypertension in the rat increases vascular superoxide production via membrane NADH/NADPH oxidase activation: contribution to alterations of vasomotor tone. $J$ Clin Invest 97: 1916-1923, 1996.

RAJAPAKSE NW, DE MIGUEL C, DAS S, MATTSON DL: Exogenous L-arginine ameliorates angiotensin II-induced hypertension and renal damage in rats. Hypertension 52: 1084-1090, 2008.

RAUCHOVÁ H, PECHÁŇOVÁ O, KUNEŠ J, VOKURKOVÁ M, DOBEŠOVÁ Z, ZICHA J: Chronic Nacetylcysteine administration prevents development of hypertension in $\mathrm{N}^{\omega}$-nitro-L-arginine methyl estertreated rats: the role of reactive oxygen species. Hypertens Res 28: 475-482, 2005.

RECKELHOFF JF, ROMERO JC: Role of oxidative stress in angiotensin-induced hypertension. Am J Physiol 284: R893-R912, 2003.

RHALEB NE, YANG XP, NANBA M, SHESELY EG, CARRETERO OA: Effect of chronic blockade of the kallikrein-kinin system on the development of hypertension in rats. Hypertension 37: 121-128, 2001. 
RODRIGUEZ-ITURBE B, PONS H, QUIROZ Y, GORDON K, RINCON J, CHAVEZ M, PARRA G, HERRERAACOSTA J, GOMEZ-GARRE D, LARGO R, EGIDO J, JOHNSON RJ: Mycophenolate mofetil prevents saltsensitive hypertension resulting from angiotensin II exposure. Kidney Int 59: 2222-2232, 2001.

ROMERO JC, RECKELHOFF JF: Role of angiotensin and oxidative stress in essential hypertension. Hypertension 34: 943-949, 1999.

SAGNELLA GA, MARKANDU ND, BUCKLEY MG, MILLER MA, SINGER DRJ, MACGREGOR GA: Hormonal responses to gradual changes in dietary sodium intake in humans. Am J Physiol 256: R1171-R1175, 1989.

SÁNCHEZ-MENDOZA A, HONG E, ESCALANTE B: The role of nitric oxide in angiotensin II-induced renal vasoconstriction in renovascular hypertension. J Hypertens 16: 697-703, 1998.

SASSER JM, POLLOCK JS, POLLOCK DM: Renal endothelin in chronic angiotensin II hypertension. Am J Physiol 283: R243-R248, 2002.

SCHNERMANN JB, TRAYNOR T, YANG T, HUANG YG, OLIVERIO MI, COFFMAN T, BRIGGS JP: Absence of tubuloglomerular feedback responses in AT1A receptor-deficient mice. Am J Physiol 273: F315-F320, 1997.

SCHOONMAKER GC, FALLET RW, CARMINES PK: Superoxide anion curbs nitric oxide modulation of afferent arteriolar ANG II responsiveness in diabetes mellitus. Am J Physiol 278: F302-F309, 2000.

SHELAT SG, KING JL, FLANAGAN-CATO LM, FLUHARTY SJ: Mineralocorticoids and glucocorticoids cooperatively increase salt intake and angiotensin II receptor binding in rat brain. Neuroendocrinology 69: 339351, 1999.

SHOKOJI T, FUJISAWA Y, KIMURA S, RAHMAN M, KIYOMOTO H, MATSUBARA K, MORIWAKI K, AKI Y, MIYATAKE A, KOHNO M, ABE Y, NISHIYAMA A: Effects of local administrations of tempol and diethyldithio-carbamic on peripheral nerve activity. Hypertension 44: 236-243, 2004.

SILVA GB, GARVIN JL: Angiotensin II-dependent hypertension increases Na transport-related oxygen consumption by the thick ascending limb. Hypertension 52: 1091-1098, 2008.

SULLIVAN JC, POLLOCK DM, POLLOCK JS: Altered nitric oxide synthase 3 distribution in mesenteric arteries of hypertensive rats. Hypertension 39: 597-602, 2002.

TAN DY, MENG S, CASON GW, MANNING RD JR: Mechanisms of salt-sensitive hypertension: role of inducible nitric oxide synthase. Am J Physiol 279: R2297-R2303, 2000.

TIAN N, ROSE RA, JORDAN S, DWYER TM, HUGHSON MD, MANNING RD JR: N-acetylcysteine improves renal dysfunction, ameliorates kidney damage and decreases blood pressure in salt-sensitive hypertension. J Hypertens 24: 2263-2270, 2006.

TIAN N, MOORE RS, PHILLIPS WE, LIN L, BRADDY S, PRYOR JS, STOCKSTILL RL, HUGHSON MD, MANNING RD JR: NADPH oxidase contributes to renal damage and dysfunction in Dahl salt-sensitive hypertension. Am J Physiol 295: R1858-R1865, 2008.

TOJO A, KIMOTO M, WILCOX CS: Renal expression of constitutive NOS and DDAH: separate effects of salt intake and angiotensin. Kidney Int 58: 2075-2083, 2000.

TOLINS JP, SHULTZ PJ: Endogenous nitric oxide synthesis determines sensitivity to the pressor effect of salt. Kidney Int 46: 230-236, 1994.

TOMOHIRO A, KIMURA S, HE H, FUJISAWA Y, NISHIYAMA A, KIYOMOTO K, AKI Y, TAMAKI T, ABE Y: Regional blood flow in Dahl-Iwai salt-sensitive rats and the effects of dietary L-arginine supplementation. $\mathrm{Am}$ J Physiol 272: R1013-R1019, 1997.

USUI M, EGASHIRA K, KITAMOTO S, KOYANAGI M, KATOH M, KATAOKA C, SHIMOKAWA H, TAKESHITA A: Pathogenic role of oxidative stress in vascular angiotensin-converting enzyme activation in long-term blockade of nitric oxide synthesis in rats. Hypertension 34: 546-551, 1999.

VANĚČKOVÁ I, KRAMER HJ, NOVOTNÁ J, KAZDOVÁ L, OPOČENSKÝ M, BADER M, GANTEN D, ČERVENKA L: Roles of nitric oxide and oxidative stress in the regulation of blood pressure and renal function in prehypertensive Ren-2 transgenic rats. Kidney Blood Press Res 28: 117-126, 2005.

VARELA M, HERRERA M, GARVIN JL: Inhibition of Na-K-ATPase in thick ascending limbs by NO depends on $\mathrm{O}_{2}{ }^{-}$ and is diminished by a high-salt diet. Am J Physiol 287: F224-F230, 2004.

VON THUN AM, VARI RC, EL-DAHR SS, NAVAR LG: Augmentation of intrarenal angiotensin II levels by chronic angiotensin II infusion. Am J Physiol 266: F120-F128, 1994. 
WANG CT, ZOU LX, NAVAR LG: Renal responses to $\mathrm{AT}_{1}$ blockade in angiotensin II-induced hypertensive rats. J Am Soc Nephrol 8: 535-542, 1997.

WANG H, CARRETERO OA, GARVIN JL: Nitric oxide produced by THAL nitric oxide synthase inhibits TGF. Hypertension 39: 662-666, 2002.

WANG HD, XU S, JOHNS DG, DU Y, QUINN MT, CAYATTE AJ, COHEN RA: Role of NADPH oxidase in the vascular hypertrophic and oxidative stress response to angiotensin II in mice. Circ Res 88: 947-953, 2001.

WANG T, GIEBISCH G: Effects of angiotensin II on electrolyte transport in the early and late distal tubule in rat kidney. Am J Physiol 271: F143-F149, 1996.

WEINBERGER MH, FINEBERG NS, FINEBERG SE, WEINBERGER M: Salt sensitivity, pulse pressure, and death in normal and hypertensive humans. Hypertension 37: 429-432, 2001.

WELCH WJ, TOJO A, WILCOX CS: Roles of NO and oxygen radicals in tubuloglomerular feedback in SHR. Am $J$ Physiol 278: F769-F776, 2000.

WELCH WJ, MENDONCA M, ASLAM S, WILCOX CS: Roles of oxidative stress and $\mathrm{AT}_{1}$ receptors in renal hemodynamics and oxygenation in the post-clipped 2K1C kidney. Hypertension 41: 692-696, 2003.

WELCH WJ, BLAU J, XIE H, CHABRASHVILI T, AND WILCOX CS: Angiotensin-induced defects in renal oxygenation: role of oxidative stress. Am J Physiol 288: H22-H28, 2005.

WILCOX CS: Oxidative stress and nitric oxide deficiency in the kidney: a critical link to hypertension? Am J Physiol 289: R913-R935, 2005.

WILCOX CS, WELCH WJ: Interaction between nitric oxide and oxygen radicals in regulation of tubuloglomerular feedback. Acta Physiol Scand 168: 119-124, 2000.

WINK DA, MIRANDA KM, ESPEY MG, PLUTA RM, HEWETT SJ, COLTON C, VITEK M, FEELISCH M, GRISHAM MB: Mechanisms of the antioxidant effects of nitric oxide. Antioxid Redox Signal 3: 203-213, 2001.

WU F, PARK F, COWLEY AW JR, MATTSON DL: Quantification of nitric oxide synthase activity in microdissected segments of the rat kidney. Am J Physiol 276: F874-F881, 1999.

XU H, FINK GD, GALLIGAN JJ: Nitric oxide-independent effects of tempol on sympathetic nerve activity and blood pressure in DOCA-salt rats. Am J Physiol 283: H885-H892, 2002.

YAMADA SS, SASSAKI AL, FUJIHARA CK, MALHEIROS DM, DE NUCCI G, ZATZ R: Effect of salt intake and inhibitor dose on arterial hypertension and renal injury induced by chronic nitric oxide blockade. Hypertension 27: 1165-1172, 1996.

ZATZ R, BAYLIS C: Chronic nitric oxide inhibition model six years on. Hypertension 32: 958-964, 1998.

ZHANG W, EDWARDS A: A model of nitric oxide tubulovascular cross talk in a renal outer medullary cross section. Am J Physiol 292: F711-F722, 2007.

ZHOU MS, SCHULMAN IH, RAIJ L: Role of angiotensin II and oxidative stress in vascular insulin resistance linked to hypertension. Am J Physiol 296: H833-H839, 2009.

ZICHA J, DOBEŠOVÁ Z, KUNEŠ J: Relative deficiency of nitric oxide-dependent vasodilation in salt-hypertensive Dahl rats: the possible role of superoxide anions. J Hypertens 19: 247-254, 2001.

ZICHA J, DOBEŠOVÁ Z, KUNEŠ J: Antihypertensive mechanisms of chronic captopril or N-acetylcysteine treatment in L-NAME hypertensive rats. Hypertens Res 29: 1021-1027, 2006.

ZOU AP, WU F, COWLEY AW: Protective effect of angiotensin II-induced increase in nitric oxide in the renal medullary circulation. Hypertension 31: 271-276, 1998. 